\title{
An overview of marine fisheries management in China
}

Gongming Shen

Mikko Heino (heino@iiasa.ac.at)

\section{Approved by}

Ulf Dieckmann

Director, Evolution and Ecology Program

June 2015

Interim Reports on work of the International Institute for Applied Systems Analysis receive only limited review. Views or opinions expressed herein do not necessarily represent those of the Institute, its National Member Organizations, or other organizations supporting the work. 


\title{
An overview of marine fisheries management in China
}

\author{
Gongming Shen $^{\mathrm{a}, *}$, Mikko Heino ${ }^{\mathrm{b}, \mathrm{c}, \mathrm{d}}$ \\ ${ }^{a}$ Fisheries Resource and Environment Research Center, Chinese Academy of Fishery Sciences, No.150 Qingta, Yongding Rd, \\ Beijing 100141, P.R.China \\ ${ }^{\mathrm{b}}$ Department of Biology, University of Bergen, Box 7803, N-5020 Bergen, Norway; \\ 'Institute of Marine Research, Box 1870 Nordnes, N-5817 Bergen, Norway; \\ ${ }^{\mathrm{d}}$ International Institute for Applied Systems Analysis (IIASA), A-2361 Laxenburg, Austria
}

\begin{abstract}
China is the world's largest country in terms of fish production, yet its fisheries management is comparatively unknown outside the country. This article gives an overview of the current management system and highlights some of its challenges. In the past thirty years, the Department of Fishery Administration has formulated and organized a series of conservation and management regimes and measures. The most important tools are minimum mesh size regulation and a range of input control measures, including seasonal closures and attempts to control fishing capacity through licensing and limiting total engine power. However, fisheries output is only controlled through a nation-wide total catch limit. Certain progress has been achieved, but there are still problems as the resource situation is poor. While the existing measures could, in principle, improve sustainability, their enforcement is insufficient, and they do not limit fishing effort in a way that would allow recovery.
\end{abstract}

Keywords: Marine fisheries management, Domestic marine catch, Regimes and measures

\section{Introduction}

The People's Republic of China (here after referred to as 'China') is the world's biggest producer of both wild and farmed fish [1]. The increase of Chinese fishery production by one order of magnitude from 1950 to 2000 [2] could be seen as a success story, yet Chinese fisheries have mostly attracted negative publicity in international media. These relate to misreporting of catches [3], disputes about ownership of waters surrounding China [4], the growing footprint of Chinese demand for fishery products such as sea cucumbers outside China [5], and most recently, the activities of Chinese distant-water fleets [6]. At the same time, comparatively little information about Chinese fisheries and how they are managed is actually available outside China. This is probably because the information published by the Chinese government is almost exclusively in Chinese, and the bulk of scientific literature is also in Chinese. This makes much of the information relatively inaccessible outside China.

The goal of this paper is to give an overview about marine fisheries management in China since the reform and opening of China. The existing reviews on fisheries management in China are more than two decades old [7, 8] and do not reflect the current situation. This paper starts with a brief introduction to the history of marine fisheries in China, followed by a description of the development of marine fisheries since 1980. Then the marine fisheries management is described, including its goals, how it is organized, and the kinds of measures in use. The present challenges in marine fisheries and possible ways forward are discussed in the final part.

\section{The history of marine fisheries from 1950 to present}

\footnotetext{
*Corresponding author. Fisheries Resource and Environment Research Center, Chinese Academy of Fishery Sciences, No.150 Qingta, Yongding Rd, Beijing 100141, P.R. China.

E-mail address: sgm@cafs.ac.cn, Tel: +86 13522093101
} 
Major achievements have been made in the development of Chinese marine fisheries since the new China was founded in 1949. The total marine catch is up from 0.6 million tons in 1950, to 13.6 million tons in 2011, over 20-fold increase, and mariculture production has increased from 0.15 million tons in 1954 to 15.5 million tons in 2011, nearly 100 -fold increase $[9,10]$. In the past decade Chinese total marine catch and mariculture production accounted for nearly $1 / 5$ and $2 / 3$ of the global output, respectively. The value of Chinese marine fishery production reached 342 billion Yuan (approximately 40 billion euro) in 2011 [11].

The most prominent feature in marine fishery catches is the period of fast growth from the 1980s to the end of the $20^{\text {th }}$ century (Fig. 1). From the perspective of the fishery resources, however, the development of Chinese marine fishing industry has experienced four different stages [7, 8, 12-16]:

- The first period in the 1950 s was a period of steady development. The potential of marine fishery resources was big. With the increase of fishing capacity and improvement of technology, fish catches rose steadily. Most catches were the traditional fishery species living near the sea floor, such as hairtail (Trichiurus lepturus), small yellow croaker (Larimichthys (=Pseudosciaena) polyactis), and big yellow croaker (Larimichthys (=Pseudosciaena) crocea).

- The second period is in the 1960s. During this period the fishery resources began to be fully utilized. Fishing catch fluctuated and CPUE (Catch Per Unit Effort) began to decrease over the following decade. In addition, the percentage of catches representing traditional fishery species began to decline. Smaller and younger fishes as well as new, low-value species, such as anchovy (Engraulis japonicus), started to appear in the landings.

- The third period is from 1970s to the mid-1980s. During this period the development of Chinese marine fishing accelerated. The catches were mainly promoted by increasing fishing effort. The percentage of traditional fishery species became lower and lower. Traditional peak fishing seasons for most traditional fishery species no longer gave good catches, and some species even disappeared altogether. Most catches came from small, low-quality fishes and were from upper-middle layer of the sea. Fish resources were in a stage of severe recession.

- The fourth period is from the middle of the 1980 s to the present day. The marine catch leapt during this period. It is also the peak period for marine fishery resource management. In 1985, the Chinese government put forward a policy that calls for simultaneous development of aquaculture, fishing and processing, with a special emphasis on aquaculture and gradually developed distant-water fisheries.

\section{The development of marine fishing since 1980}

Before the 1980s, growth of fisheries in China mainly relied on quantity. In the 1990s, the form of fisheries growth began to be more focused on quality and ecological benefits, that is, shifting from "extensive" to "intensive" growth.

\subsection{Management objectives}

Objectives of fisheries management in China are stated in official policy documents. In 2006, the Chinese government promulgated the "Program of Action on the Conservation of Living Aquatic Resources of China [18]" that reflects the Chinese government's focus not only on the development of economy, but also on the conservation of the fisheries resources and environment. The program states the following medium-term objective: "By the year of 2020, the aquatic environment should be gradually rehabilitated, the trend of decline of fishery resources and increase of endangered species should be kept within limits, and fishing capacity and catch from marine capture fisheries should generally accommodate the supporting ability of fishery resources." In other words, the stated overall objective is ecological sustainability. 
Furthermore, the program also states the means to reach that objective: "The total number of marine fishing vessels with engine, power and domestic marine catch should be reduced to 160,000, 10 million kilowatts and 10 million metric tons respectively. The number of stock enhancement for key fishery species should be over 40 billion tails (eggs) each year. The number of natural reserves for living aquatic resources above provincial level should be over 200. The percentage of investigation and punishment of pollution accidents in fishery water areas should be over $80 \%$."

\subsection{Administrative framework}

According to the Fisheries Law of the People's Republic of China, revised in 2004, "In its supervision over the fisheries, the State applies the principle of unified leadership and decentralized administration at different levels. With the exception of those sea areas that the State Council puts under the supervision of the administrative department for fisheries under it or of the fisheries authorities subordinate to the department and those fishing grounds endowed with special fishery resources designated as such by the State Council, marine fisheries shall be subject to supervision by the administrative departments for fisheries under the people's governments of provinces, autonomous regions and municipalities directly under the Central Government that are contiguous to the sea areas [19]."

From the perspective of different functions, management organization can be roughly divided into four parts:

1) The main administrative department is the Bureau of Fisheries under the Ministry of Agriculture (MOA), the highest body in fisheries administration.

2) Administration of Fishery and Fishing Harbor Supervision, whose main task is the inspection and supervision of fishing ports and vessels and exercising administrative and supervisory authority over external relations pertaining to fisheries and fishing ports.

3) Scientific research institutions, such as the Chinese Academy of Fishery Sciences and the fishery universities, that focus on carrying out the research and putting forward related suggestions to government departments.

4) Social organizations, such as the China Fisheries Association, which are mainly responsible for informing and advising fishermen about fisheries technology as well as policies and regulations.

\subsection{Fishers, engine-powered fishing vessels and engine power}

Despite the goals of the Chinese government to carry out fisherman relocations, reduce the numbers of fisheries, and to control the numbers of fishing vessels and their total engine power, the number of fishers tripled from about 1,224,000 in 1980 to 3,690,000 in 2011 (Fig. 2a). Although the number of fishing vessels has been declining in the past ten years, their total engine power is still showing a rising trend (Fig. $2 b)$.

\subsection{The catches by area, gear, and habitat}

Marine fisheries in China are concentrated in the four coastal seas surrounding the country. They are, from the north to the south, the Bohai Sea, the Yellow Sea, the East China Sea and the South China Sea. Of these, the fish catch in the East China Sea is the highest and accounts for about $40 \%$ of the total catch (Fig. 3). However, the dominance of the East China Sea has declined over time. The dominant fishing gear in terms of landings is trawl, accounting for on average $46 \%$ of the domestic marine catches. Other important gear, with respective catch percentages, are stow net (17\%), drift gillnet (14\%), purse seine (9\%) and long-line (3\%) (Fig. 4). 
Fisheries in China have traditionally targeted fish in the coastal and inshore areas. Since 1985, however, China started to develop distant-water fisheries, with good results [6, 13, 22]. The peak catches were about 1.45 million tons in 2004 (Fig. 5). In comparison to the domestic marine catch, however, the catch from distant-water fisheries only accounted for less than $10 \%$.

\section{Management measures}

Since China's reform and opening up, the Department of Fishery Administration has formulated a series of measures to improve management of the marine resources, including the fishing license system, the minimum mesh size regulation, the so-called "Double Control" system, summer fishing moratoria, fishing catch limit regimes, fishery enhancement programs, establishment of artificial reefs, and aquatic germplasm resource protection areas.

\subsection{Fishing license system}

In 1979, the State Council promulgated the "Regulation on the Breeding and Protection of Aquatic Resources". It was the first time a fishing license system as a form of administrative regulation was put forward. According to the Fisheries Law of the People's Republic of China (1986), any unit or individual that intends to engage in inland or inshore fishing must first apply the regional department of fishery administration for a fishing license [24]. In 1989 MOA issued "Regulation on Fishing Licenses" which was revised in 1997. This regulation specified the license system, but there were some obvious problems, namely that the rules were difficult to implement because they were not specific enough [25].

In 2000, MOA organized the first national census of marine fishing vessels. The result showed that there were still 67,200 illegal vessels which did not have fishing licenses, fishing vessel registration certificates, and fishing vessel inspection certificates, accounting for $27.5 \%$ of all vessels [26]. The large number of illegal vessels was one of the main reasons for excessive fishing effort.

In 2002, to strengthen the management of fishing licenses, MOA promulgated the "Regulation on Fishing Permit Management." This regulation made specific provisions on the qualifications for obtaining the fishing license, the fishing areas, the numbers of allowed fishing gear, and punishments for violating the regulations. This regulation has been amended in 2004 and 2007.

\subsection{Minimum mesh size regulation}

In China, the research on minimum mesh size began in the 1970s. However, mesh size regulations were not implemented until much later. Article 30 of the Fisheries Law of the People's Republic of China states that it is not permitted to use fishing nets with meshes smaller than the minimum mesh size [27]. Only after 2004, MOA began to fully implement minimum mesh size regulations. The minimum allowed mesh size depends on the fishing gear as well as fishing area (Table 1).

Minimum mesh size regulation is a very important means to protect fishery resources in China. However, it can be noticed there are still some problems (Table 1). First, there is a very small number of legally binding standards for mesh size, only six at present. As there are at least 40 main commercial species of fish and over 10 fishing gears in Chinese seas, the existing standards leave many fishing gears and fish species outside the regulation. Moreover, there is no rule concerning shrimps and crabs. Second, the standards need updating. Table 1 shows that some minimum mesh size regulations are based on research finished in 1980s, but the status of fisheries resources in China has greatly changed in the past 30 years [29]. 


\section{3 "Double Control" system}

In order to relieve pressure on marine fisheries resources and control the fishing effort, in 1987 MOA proposed the so-called "Double Control" system, referring to the control of both the total number of marine engine-powered fishing vessels and their total engine power. The results do not show a good overall effect. In many coastal areas, the "Double Control" system has not been fully implemented [30]. From 1986 to 2002 the number of marine fishing vessels increased by more than 60,000 and their engine power more than doubled (Table 2).

In 2003, MOA issued "Implementation Attitude on Control of Marine Fishing Vessels of the Period of 2003-2010"1 which put forward a clear objective as well as specific requirements for the implementation. The objective was to reduce the numbers and total engine power of the fishing fleet by respectively 30,000 vessels and about 1.27 million kilowatts by 2010. However, Figure $2 \mathrm{~b}$ and Table 2 show that although the number of fishing vessels has declined since 2003 , the total engine power has been steadily rising, except in 2003. Indeed, the total engine power reached a new high in 2011.

In general, the "Double Control" system has not achieved its goals. There are some main problems which can explain its low effect:

1) The limited inspection by the local governments. To develop local economy and guarantee the fishermen's income, the inspections of fishing vessels and their power are not very strict, especially not for the power. Sometimes low-power engines have been replaced by high-power engines, while the nameplate may show a lower nominal power, to the joint benefit of shipyards and engine manufacturers. This phenomenon has become an open secret in the industry [30, 34].

2) Illegal fishing vessels. Many fishing vessels were manufactured illegally. At present it is forbidden to manufacture new marine fishing vessels, except through remanufacturing or renovation according to the regulation. In addition, some marine fishing vessels do not have the fishing license.

3) New fishers. Despite of relocation of some fishermen, there are also some new fishers, contributing to the increasing number of fishing vessels and their engine power.

\subsection{Summer moratorium of fishing}

To reduce the pressure of the fishery resources, since 1995 a summer moratorium has been implemented in the Bohai, Yellow, and East China Seas. The objective is to protect the main commercial fish resources, such as hairtail and large yellow croaker. Starting in 1999, the summer moratorium was also implemented in the South China Sea. The summer moratorium is a very important measure to protect the marine fishery resources in China by ensuring that most species have a chance to spawn. Since 2009, in response to the severe decline in the state of the fishery resources and the rising temperature of sea water, MOA adjusted the summer moratorium system: the starting date of the moratorium was advanced by 15 days, while the closing date was kept unchanged, thus extending the total duration of the moratorium (Table 3).

The summer moratorium functions well in protecting the marine fishery resources during the closure time, but its effect is short-lasting [36-38]. In the long term, the system has a very limited effect:

1) After the moratorium, it is hard to control the fishing effort. Nearly all the marine fishing vessels rush into the sea at once. Because of this huge fishing effort, the achievements of the moratorium will disappear in 2-3 months and the resource density will fall to a low level after autumn. This is the main problem.

2) Due to the high diversity of marine species in China, the spawning times of different species may

\footnotetext{
${ }^{1}$ This is the official translation, but an alternative translation "Recommendations for Controlling the Numbers of Marine Fishing Vessels in the Period 2003-2010" better conveys the meaning.
} 
not overlap with the moratorium. The current moratorium system lacks specificity to sufficiently cover the spawning seasons of different species.

3) Some researchers have argued that China missed the best opportunity to recover fisheries resources: the best time to establish the moratorium system was in the late 1960s when resources began to decline. However, the moratorium system was only established in 1995, which made the effect limited [16, 37, 38].

\subsection{Fishing catch limit regime}

To mitigate the pressure of the fishing effort, China started to consider controlling the total catch of marine fishery using a fishing catch limit regime, no longer regarding high catches as a political achievement of the local government. In 1999 MOA proposed the "Zero Growth" policy, that is, the domestic marine catch of 1999 was not to be higher than that of 1998. Thus, a kind of Total Allowable Catch (TAC) system was introduced. In 2000, in order to strengthen the implementation of the policy, MOA proposed the "Negative Growth" policy.

The "Zero Growth" and "Negative Growth" policies have been effective. As seen in Figure 1, China's total marine catch began to decline since 2000, and has stayed at that level in the past decade. Given the depletion of the marine fishery resources, while at the same time the need to protect livelihoods of fishermen (considered being a vulnerable group), the fishing catch limit regime which controls the total catch and maintains the catch levels seems to be an appropriate measure [39].

\subsection{Establishment of artificial reefs}

Since the 1970s, departments concerned with fishery administration started to consider restoring the fishery resources by habitat improvements. In 1979-1987, the Chinese government began to test artificial reefs in the coastal areas [40, 41]. Since 2001, the government gradually began to invest in building artificial reefs [41-43]. Some studies have shown that the establishment of artificial reefs has brought obvious positive effect $[41,44,45]$. Unfortunately, so far there is no systematic survey to illustrate the benefits of the artificial reefs.

\subsection{Fishery resources enhancement}

In China fishery resources enhancement began in the 1950s. Figure 6 shows a rising trend in marine stock enhancement in the past decade. During this time, stock enhancement has been one of the most important management measures of the Chinese government to restore marine fishery resources. The total marine stock enhancement was 17.9 billion juvenile fish in 2001-2005, totaling 36.0 billion in 2006-2010. In 2010, MOA issued "Overall Planning of National Stock Enhancement of Aquatic Organism in the period of 2011-2015," which determines the guiding ideology, goals and implementation measures of stock enhancement for that five year period. The investment in stock enhancement is thus set to continue.

Some research has suggested that fishery resource enhancement has played a positive role in recovering fishery resources [46, 47]. However, a systematic evaluation of the effect is still lacking [48].

\subsection{Aquatic germplasm resources protection areas}

Article 29 of the Fisheries Law of the People's Republic of China states that in major growing and breeding areas of living aquatic resources with high economic and hereditary value, aquatic germplasm resources protection areas (AGRPAs) should be built up [51]. This official title highlights the goal of protecting genetic resources of aquatic species in comparison with other reserves, but they also provide habitat protection. 
In 2007, establishing the first batch of these protected areas started. In 2011, MOA issued "Interim Measures for the Administration of Aquatic Germplasm Resources Protection Area" which aimed at strengthening and standardizing the management of the protected areas. By 2011, China had established 282 AGRPAs, 37 of them in the marine environment.

The establishment of AGRPAs is one of the most important new management measures in China over the past five years. At present, however, the establishment of AGRPAs is still at the initial stage. The AGRPAs lack specialized management agency and the funds to undertake substantial protection. In addition, the ordinary people have very little knowledge about AGRPAs, and many people do not know the role of the AGRPAs [52]. At present, the actual level of protection offered by the AGRPAs remains limited.

\section{Challenges}

Since China's reform and opening, many protection measures related to marine fisheries resources have been implemented. However, some of these measures have not achieved the anticipated effects [53-55]. The problems of resource declines and environmental deterioration are still serious [14, 53, 54, 56-58]. There are some challenges that are worth commenting.

\subsection{The fishermen's awkward situation}

The recession of marine fishery resources in China is an indisputable fact. Although the Chinese government has been trying to ensure recovery of the fisheries resources, China's marine fisheries resources are in a situation that can be likened to "the tragedy of the commons" [59, 60]. The fisheries resources in China are much like the commons: access is restricted, but the licensed fishermen can exploit the resource relatively freely. This put the fishermen in an awkward situation. On the one hand, many fishermen realize that the fishery resources are not unlimited, so it would be in common interests to protect them. On the other hand, they are not willing to give up fishing the small fishes which they know they should protect, because they know that even if they do not fish, others will.

As of 2011, there are about 3,233,000 traditional fishermen in China, and many of them live on fishing [11]. Due to the severe decline of natural resources, and the rising costs, such as oil prices, fishers are sometimes unable to maintain their normal lives. Therefore, the Chinese government has encouraged them to change their profession. However, their attachment to the traditional way of life is quite strong, and relocation is very difficult for them [61].

\subsection{Government supervision}

At present, the staff and equipment for enforcement of the fishery regulations are insufficient, and the law enforcement has not achieved good results [62,63]. For example, the minimum mesh size system has been implemented in China for nearly 10 years, but in reality, many fishing gears, such as trawls, often do not comply with the system [62]. In principle, China does have many good measures for protecting fisheries resources in place, but the reality is quite different. One of the most important reasons is the lack of efficient enforcement and supervision by the government.

\subsection{The bias against farmed fish}

Eating fish has a long history in China, and Chinese people like to eat fish, especially wild fish. However, there is cultural resistance against eating farmed fish: people do not think that the farmed fish are fresh or nutritious enough. Moreover, there are also more objective reasons for the resistance: the flavor of some farmed fish may not be as good as in wild fish (e.g., big yellow croaker), and there are also problems with 
excessive medication, ultimately caused by too high fish density in the fish farming industry [53, 64].

The bias against farmed fish is a major challenge. In principle, increased consumption of farmed fish could partly alleviate the pressure on the wild fish resources. However, because of people's preference for wild fish, the fishermen are still keen on fishing as the price of wild fish gets higher. Thus, the pressure on wild fish resources continues, despite the continual decline of fishery resources and the increasing cost of fishing. This is an important reason why it is difficult to mitigate fishing effort in the Chinese waters.

\section{Suggestions}

Here we discuss some suggestions that might help addressing the challenges outlined above.

\subsection{The regimes and measures of management should be "simple"}

China does not lack good management measures, or enthusiasm for protecting fishery resources and the environment. Many measures are suitable for China's current situation. What China does lack is good implementation of existing measures. On one side, the government enacts many good policies. On the other side, fishermen in reality ignore the policies. This is a big problem. Therefore, from the perspective of the current Chinese situation, management regimes and measures should be "simple". This would imply that the measures are more easily implemented and enforced. Otherwise, a policy will easily become just a piece of paper.

The summer moratorium of fishing, for instance, is one of the most successful measures in China Sea. There are two main reasons why this system has succeeded: 1) Compared to other measures, fishing moratorium is easier to design and needs less scientific data. 2) During the moratorium, all fishing vessels should be docked at the harbor, making it is easy for the enforcers to find the illegally fishing vessels.

At present Individual Transferable Quotas (ITQs) are a hot topic in China [14, 64]. Compared to the summer moratorium of fishing, ITQs are a complex regime. Requirements for implementing ITQ are demanding, especially concerning the enforcement. There is no doubt that ITQs can offer a good management regime, but not unless the conditions are right. At the current situation, not all measures are suitable for China.

\subsection{Strengthening enforcement}

Even if the policy is "simple," illegal fishing can still be a serious problem. Due to the Tragedy of the Commons and the low income of some fishermen, the management could not totally depend on the fisherman's consciousness to achieve the goal of efficient policy implementation. Instead of ignoring existing policies and constantly proposing new measures, the main problem to be solved is how to strengthen the implementation and enforcement of the existing policies [65]. Strengthened implementation and enforcement includes three main aspects: 1) Strengthening the establishment of enforcement groups and building up enforcement infrastructure, 2) Improving self-discipline and avoiding bribery, and 3) Increasing the penalties for illegal fishing to levels that deter such actions [64].

\subsection{Improving the awareness of fisheries resources and aquaculture industry}

Departments concerned with fisheries management should improve people's understanding of natural and aquaculture resources. In 1985, the Chinese government proposed a guiding principle of focusing on the development of aquaculture, representing its long-term vision. Following the improvement of living standards and the rising population, the demand for natural resources is growing dramatically. At the same time, the status of natural fishery resources is becoming worse. Under these conditions, developing 
aquaculture can be an efficient way for reducing the pressure on some natural resources. This would require improving the public image of farmed species, making people to realize that farmed fish can be equally nutritious as wild fish. If the market demand for natural species decreases, the willingness for fishermen to fish will naturally be reduced. Then, the excessive fishing effort could be mitigated, making it possible to restore marine fishery resources to a healthy level. Eventually, this would result in higher catches of valuable species than the current depleted state can offer.

\section{Concluding remarks}

Fisheries management in China mainly relies on technical measures (minimum mesh size regulation) and a range of input control measures. The latter include a nation-wide, seasonal fisheries closure as well as a number of ways of limiting fishing capacity (licensing and limiting the total engine power). There is no direct control of fishing effort. Output control is almost totally absent, only present as a nation-wide total catch limit.

This system has some inherent challenges, at least when seen from a perspective ensuring sustainable utilization of single species. There are no measures to protect single species, and the measures are defined at very large spatial scales. Clearly, a nation-wide total catch limit can do very little to protect a single species or a local ecosystem. The measures to control or curtail fishing capacity are relatively blunt, as limiting license numbers and engine power leaves plenty of room for technological improvements. Indeed, it has been suggested that dramatic cuts in tonnage and total power would be needed to bring the fishing capacity to the level of 1999 [66]. Outside the summer moratorium, fishers can employ as much fishing effort as they like, within the gear and engine power restrictions defined by their fishing licenses. The surge in fishing effort after the summer moratorium largely annihilates its benefits. However, one could argue that even with these relatively unspecific tools, the system could in principle ensure sustainable fisheries, if the tools were used with sufficient rigor.

Yet, given the generally poor resource situation, fisheries management in China is not delivering what it should. Here it is suggested that there are two key reasons for this. First, some conservation measures that could be effective are currently ineffective because they are set at levels that are not restrictive enough. Fishing capacity and total national catch limit are fixed at high levels that are unlikely to allow for a recovery of the resources. Furthermore, current measures for limiting fishing capacity do not preclude the increase of fishing capacity through improved fishing methods, and they do very little to curtail fishing effort. Second, enforcement of the existing regulations is not stringent enough. While the management measures are well-intentioned and potentially effective, this potential cannot not realized unless they are strictly enforced.

\section{Acknowledgements}

The corresponding author was funded through a government scholarship 2012/2013 under the Cultural Agreement between Norway and China.

\section{References}

[1] FAO. The State of World Fisheries and Aquaculture. Rome: FAO, 2012.

[2] Srinivasan UT, Watson R, Sumaila UR. Global fisheries losses at the exclusive economic zone level, 1950 to present. Marine Policy 2012; 36: 544-9. 
[3] Watson R, Pauly D. Systematic distortions in world fisheries catch trends. Nature 2001; 414: 534-6.

[4] Mallory TG. The Sea's Harvest: China and Global Fisheries. Saisphere 2011-2012; 36-40.

[5] Anderson SC, Flemming JM, Watson R, Lotze HK. Serial exploitation of global sea cucumber fisheries. Fish and Fisheries 2011; 12: 317-39.

[6] Pauly D, Belhabib D, Blomeyer R, Cheung William WWL, Cisneros-Montemayor AM, Copeland D, et al. China's distant-water fisheries in the 21st century. Fish and Fisheries 2013; 1-15.

[7] Yu HM. Marine fishery management in PR China. Marine Policy 1991; 15: 23-32.

[8] Wang SDH, Zhan BY. Marine fishery resource management in PR China. Marine Policy 1992; 16: 197-209.

[9] The appendix in China Fisheries Yearbook 2007 [in Chinese].

[10] The appendix in China Fisheries Yearbook 2012 [in Chinese].

[11] China Fisheries Yearbook 2012 [in Chinese].

[12] Wu ZY. Study on effective management of China's marine fishery resources based on sustainable development. Jilin University China; 2009 [in Chinese].

[13] Li JH. Achievements, difficulties and development prospects--the retrospect and prospect of marine fishing for the past forty years in China. China Fisheries 1989; 8-9 [in Chinese].

[14] Lu XR. Study on sustainable utilization and effective management of marine fishery resources in China. HuaZhong Agriculture University; 2005 [in Chinese].

[15] Sun JT. Study on sustainable development of marine fishery of China. Ocean University of China; 2003 [in Chinese].

[16] Lin XQ. $10^{\text {th }}$ Anniversary of implementation of summer fishing moratorium--study on issues of fishery resource and resource management. Xiamen Science and Technology 2004; 11-5 [in Chinese].

[17] China Fisheries Yearbook 2007 [in Chinese].

[18] Program of Action on the Conservation of Living Aquatic Resources of China. The Bulletin of the State Council of the People's Republic of China 2006; $42-7$ [in Chinese].

[19] Article 7 in the Fisheries Law of the People's Republic of China, amended in 2004 [in Chinese].

[20] China Fisheries Yearbook 1981-2012 [in Chinese].

[21] China Fisheries Yearbook 2003-2012 [in Chinese].

[22] Xue GF. China's distant water fisheries and its response to flag state responsibilities. Marine Policy 2006; 30: 651-8.

[23] China Fisheries Yearbook 1987-2012 [in Chinese].

[24] Article 16 in the Fisheries Law of the People's Republic of China. Beijing: Law Press; 1986 [in Chinese].

[25] Liu XS, Huang SF. Study on fishing license system of China. Marine Fisheries 1999; 101-4 [in Chinese].

[26] Huang KJ. Exploration on management means of fishing license. Chinese Fisheries Economics 2001;19: 31 [in Chinese].

[27] Article 30 in the Fisheries Law of the People's Republic of China, amended in 2004 [in Chinese].

[28] Gazette of the Ministry of Agriculture of the People's Republic of China 2003 [in Chinese].

[29] Yu XJ. Protection by implementation of minimum mesh size and rational utilization of fishery resources. China Fisheries 2003; 74-7 [in Chinese].

[30] Ou HK, Yu CD. The research on effectiveness of fishing vessel "Double Control" system. Journal of Zhejiang Ocean University (Natural Science Edition) 2011; 30: 432-5, 470 [in Chinese].

[31] China Fisheries Yearbook 1987 [in Chinese]. 
[32] China Fisheries Yearbook 2003 [in Chinese].

[33] China Fisheries Yearbook 2011 [in Chinese].

[34] She YA. Preliminary analysis on the solution of fishing vessel "Double Control" system. China Fisheries 2009; 29-30 [in Chinese].

[35] Gazette of the Ministry of Agriculture of the People's Republic of China 2009 [in Chinese].

[36] Bureau of Fisheries. The background and effectiveness of marine summer moratorium and prohibition fishing period in Yangtze river. Chinese Fisheries Economics 2005; 23: 23-4 [in Chinese].

[37] Shi YR, Li YZ, Sun DF, Lu WH. Analysis the effect of summer fishing moratorium in the past decade from the resource variation, ecological protection, economic effect and social influence. China Fisheries 2008; $14-6$ [in Chinese].

[38] Cheng JH. Analysis of the limitation and prospect of current summer fishing moratorium. China Fisheries 2008; 17-9 [in Chinese].

[39] Wu Z. The Fishing-Rights on Marine Resources in China. FAO Fisheries Technical Paper 2000; 454-5.

[40] Ma HY, Guo YP, Tang ZM, Mao LS, Zhuang P. The research progress of artificial reef. Forum on Fishery Science and Technology. Shanghai 2004. Available at http://d.g.wanfangdata.com.cn/Conference_6893968.aspx [in Chinese].

[41] Zhang SY, Xu M, Wang ZH. Review of artificial reef and stock enhancement. Fishery Modernization 2010; 37: 55-8 [in Chinese].

[42] Liu P. The development status and environmental function of artificial reef. Modern Agricultural Sciences and Technology 2011; 312, 314 [in Chinese].

[43] Lou D, Shi HX, Jiao HF. Analysis on the effect of fishery resource and marine ecological environment by the artificial reef. Ningbo fifth academic conference proceedings, 2008. Available at http://d.g.wanfangdata.com.cn/Conference_7022344.aspx [in Chinese].

[44] Wang H, Chen PM, Zhang SY, Jia XP. Effect on fishery resources multiplication of artificial reefs. Guangdong Agriculture Sciences 2009; 18-21 [in Chinese].

[45] Tu Z, Zhang XM, Zhang PD, Huang GQ, Tian T, Yang BQ, et al. Artificial Reef Project in Lidao, Rongcheng-II Assessment on the Effect of Biological Resource Enhancement by the Artificial Reef. Modern Fisheries Information 2009; 24: 16-20 [in Chinese].

[46] Shen XQ, Zhou YD. Enhencing Release and Effect Assessment of Fisheries Resource in the Yangze River Estuary and Hangzhou Bay. Fishery Modernization 2007; 34: $54-7$ [in Chinese].

[47] Zhang XM, Wang XJ, Tu Z, Zhang PD, Wang YZ, Gao TX, et al. Current status and prospect of fisheries resource enhancement in Shandoug Province. Chinese Fisheries Economics 2009; 27: 51-8 [in Chinese].

[48] Li LB. Preliminary Study on Living Aquatic Resources Enhancement in China. Shanghai Ocean University; 2011 [in Chinese].

[49] Report on the State of the Fishery Eco-Environment in China 2005 [in Chinese].

[50] Report on the State of the Fishery Eco-Environment in China 2010 [in Chinese].

[51] Article 29 in the Fisheries Law of the People's Republic of China, amended in 2004 [in Chinese].

[52]Yang WB, Li JL, Feng GF, Li XS, Li HQ. Research on setting up status of national aquatic germ plasm protection areas. Chinese Fisheries Economics 2011; 29: 165-71 [in Chinese].

[53] Hou XQ. The development and measures of Chinese marine fishery situation. Guide of Sci-Tech Magazine 2012; 328-9 [in Chinese].

[54] Yu HG, Yu YJ. Fishing capacity management in China: Theoretic and practical perspectives. Marine 
Policy 2008; 32: 351-9.

[55] Li SL. The Sustainable Developing Countermeasures of Marine Fishery Economy in 8 Coastal Provinces of China. Ocean Development and Management 2009; 26: $72-5$ [in Chinese].

[56] Mu YT. The predicament and outlet of China's marine fishing. Journal of Ocean University of China (Social Sciences Edition) 2005; 1-5 [in Chinese].

[57] Ju ZJ, Han Q. The opinion of strengthening the management of sea fishery resources in China. Hebei Fisheries 2009; 48-50 [in Chinese].

[58] Tang Y, Zou WH, Hu ZM. An Analysis of Utilization Status and Management of Marine Fisheries Resources in China based on Statistics Data. Resources Science 2009; 31: 1061-8 [in Chinese].

[59] Lin GJ. A study on the market disposition and policy in public fishery resource. Journal of Fujian Fisheries 2005; 1-4 [in Chinese].

[60] Wang M, Qin M. A game analysis on stakeholder of the development of marine fishery. Chinese Fisheries Economics 2007; 25: 19-23 [in Chinese].

[61] Chen HM. Fisheries resources management research base on sustainable development. South China University of Technology; 2009 [in Chinese].

[62] Wang L. Research on the current status of fishery administration from the perspective of fishery research and the production of vessels. Fishery Administration 2005; 26-8 [in Chinese].

[63] Xiao L, Li MS. The talk of fishery development of "twelfth five-year" from Chen Yide, the director of China Fishery Law Enforcement Command. China Fisheries 2011; 5-8 [in Chinese].

[64] Mu YT, Liang ZL. Summary of feasibility study on fishing quota system. Chinese Fisheries Economics 2010; 28: 38-42 [in Chinese].

[65] He GZ, Zhang L, Mol APJ, Lu YL, Liu JG. Revising China's Environmental Law. Science 2013; 341: 133.

[66] Zheng Y, Zhou YQ. Measures of the fishing capacity of Chinese marine fleets and discussion of the methods. Journal of Oceanography 2005; 61: 623-30.

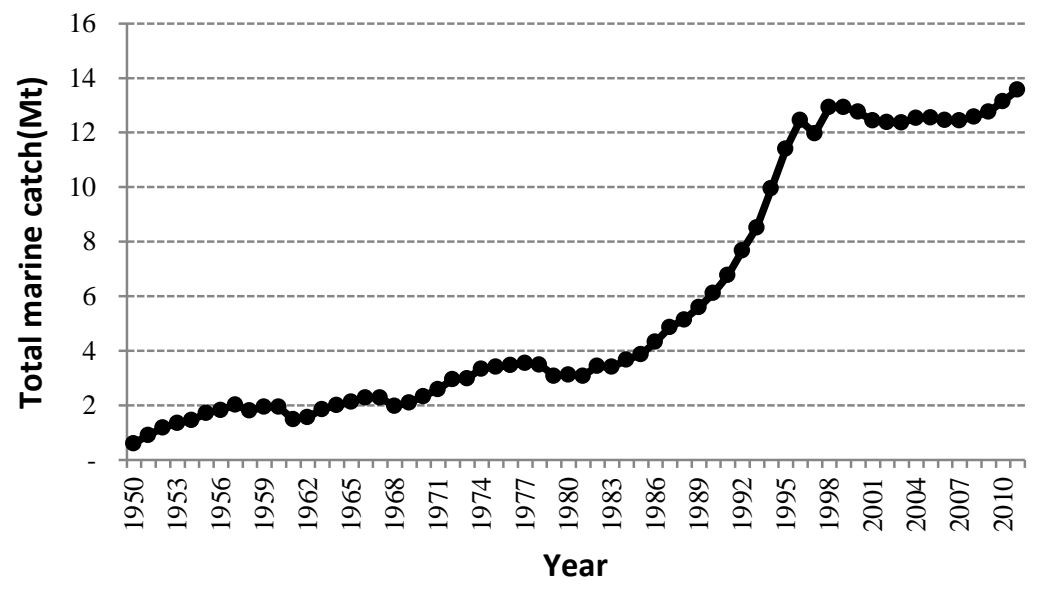

Fig. 1. Total marine catch in 1950-2011. Catch data are based on the revised catch statistics (see discussion in Box 1 of [1]). The total marine catch does not include the landings from the distant waters before 1985, but these are assumed to have been minor. Source: China Fisheries Yearbook 2006, 2011. 

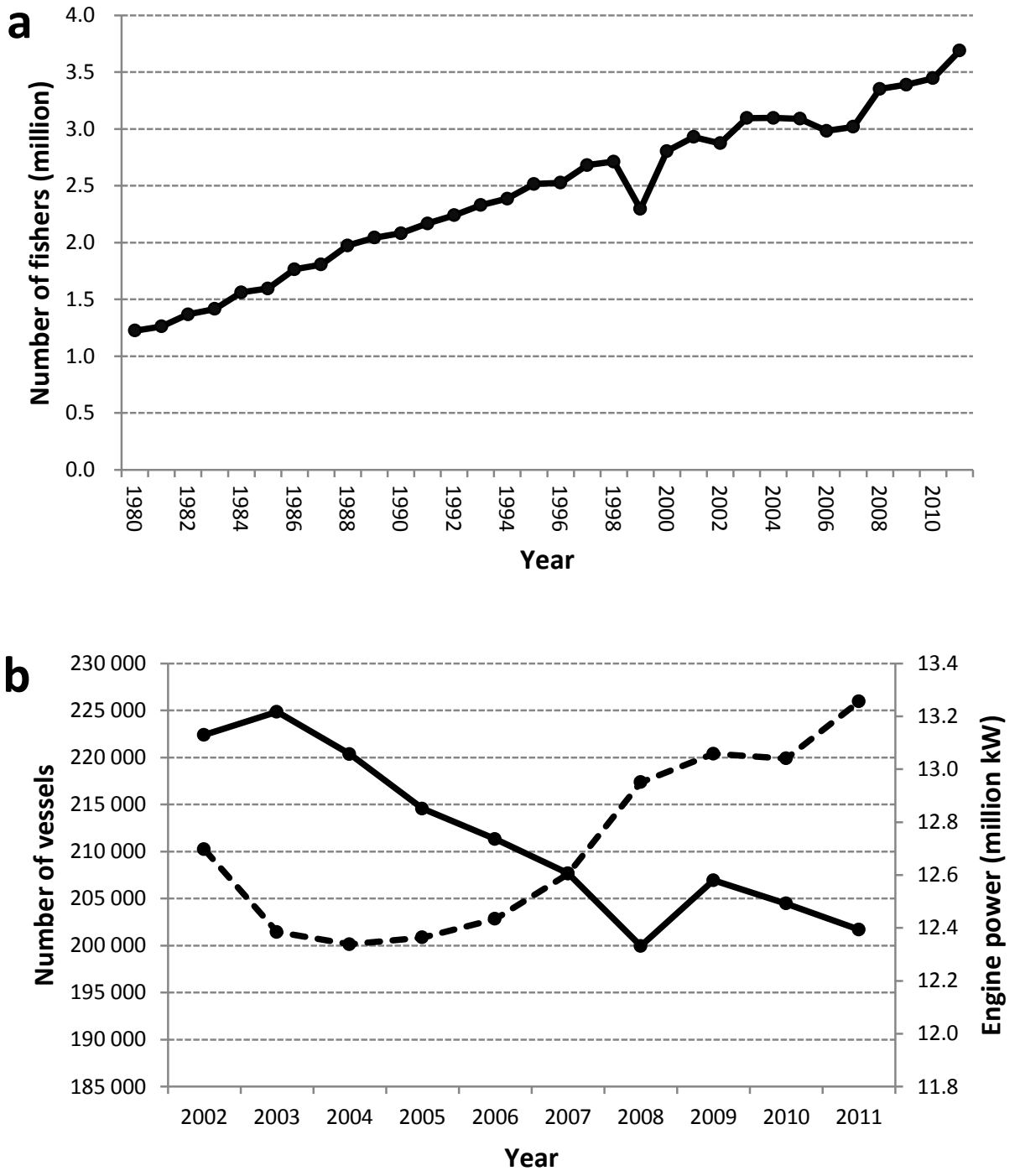

Fig. 2. The numbers of fishers, engine-powered fishing vessels and engine power. (a) The number of fishers in 1980-2011. Source: China Fisheries Yearbooks 1980-2011. (b) The number of marine engine-powered fishing vessels and their total engine power in 2002-2011. Source: China Fisheries Yearbooks 2002-2011. 


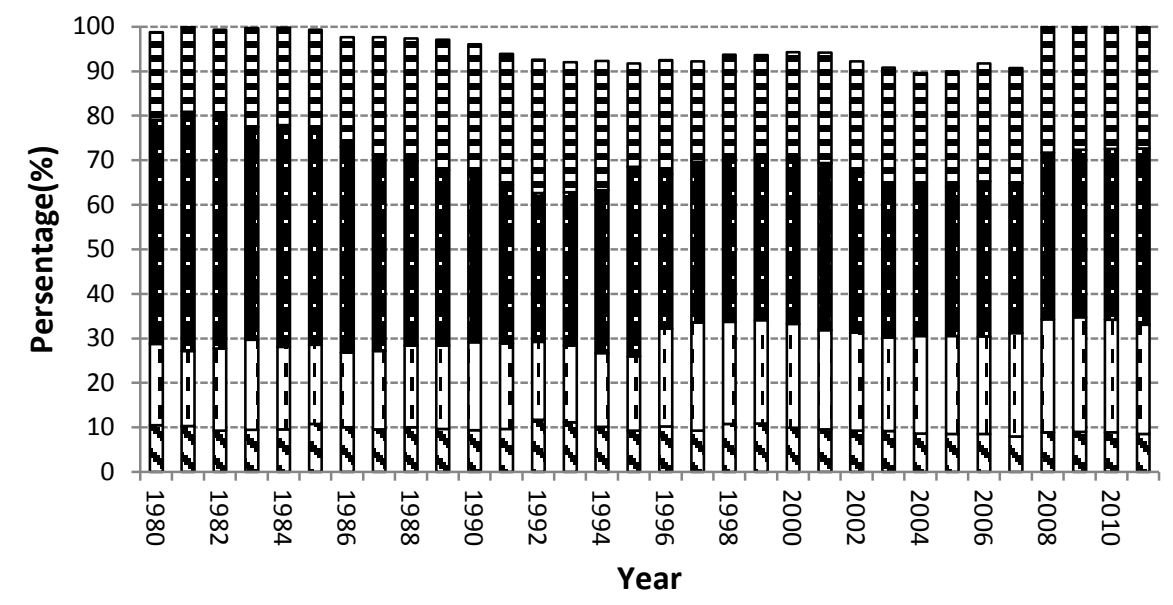

DBohai Sea $\square$ Yellow Sea East China Sea $\square$ South China Sea

Fig. 3. The percentage of the catches in different seas in 1980-2011. Source: China Fisheries Yearbooks 1980-2011.

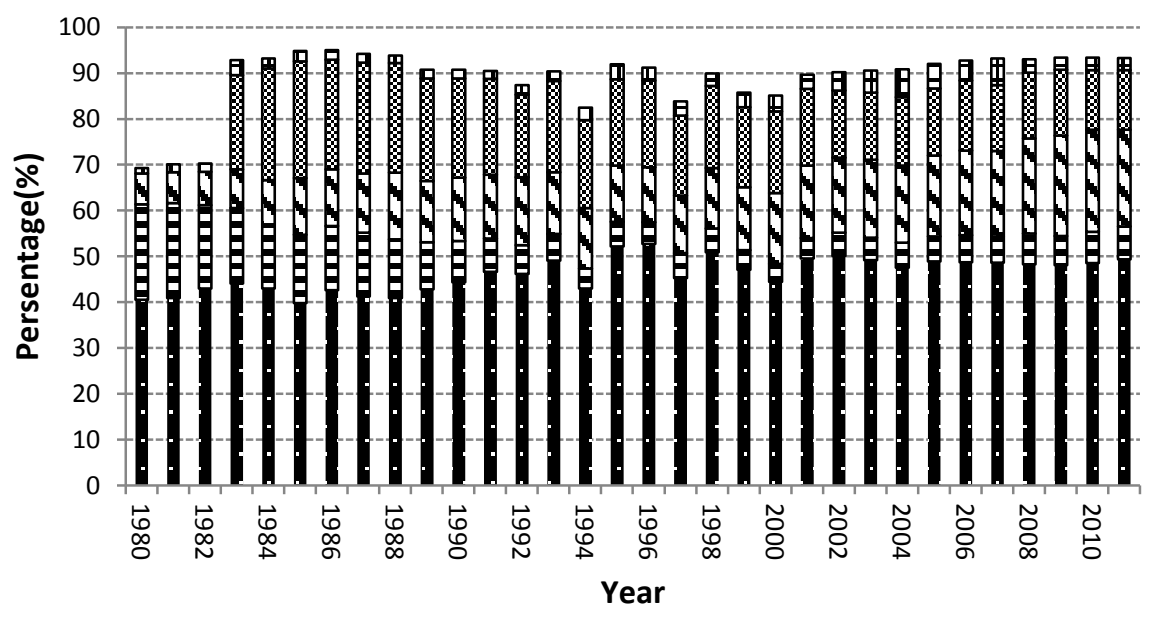

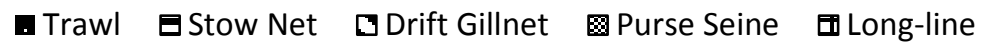

Fig. 4. The percentage of the catches of different fishing gears in 1980-2011. Source: China Fisheries Yearbooks 1980-2011. 


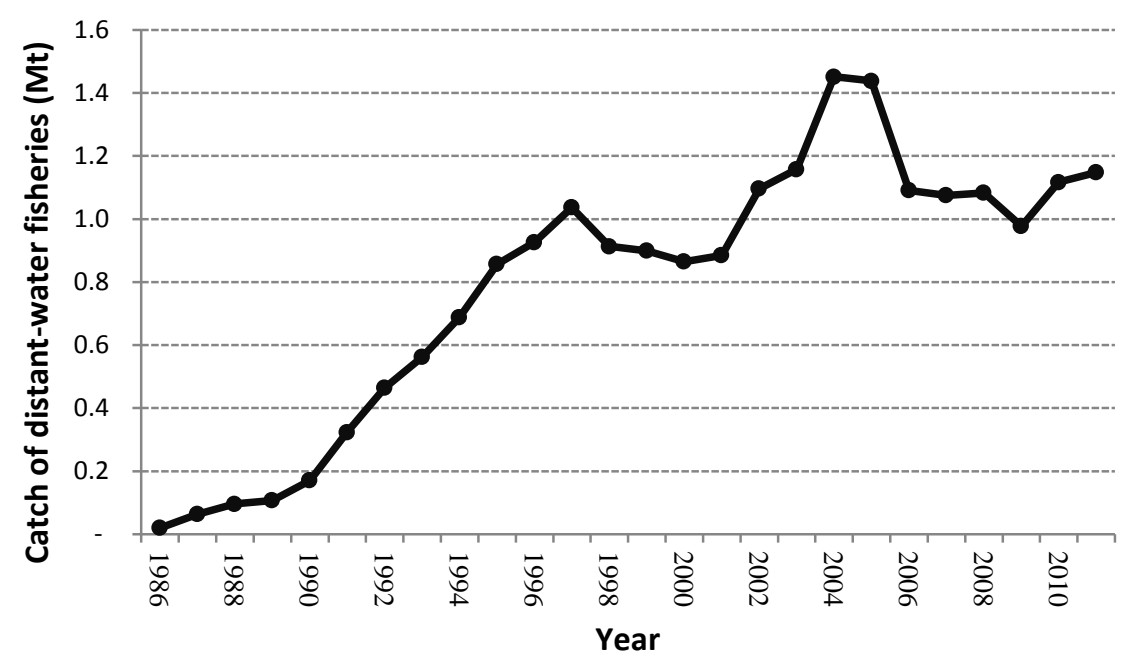

Fig. 5. The catch of distant-water fisheries in 1986-2011. Source: China Fisheries Yearbooks 1986-2011.

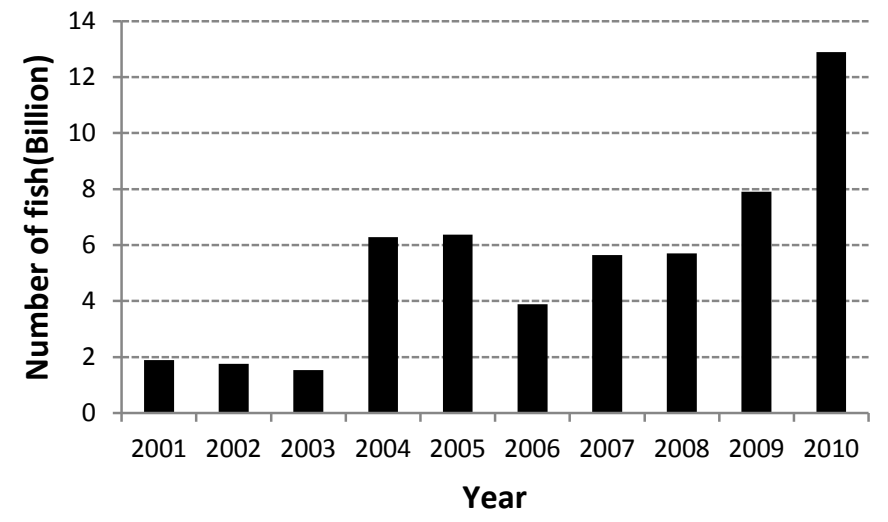

Fig. 6. The number of fish used in marine stock enhancement in 2001-2010. Source: Report on the State of the Fishery Eco-Environment in China 2005, 2010. 
Table 1.

Minimum mesh size (MMS) regulations.

\begin{tabular}{|c|c|c|c|c|}
\hline \multirow{2}{*}{ Gears } & \multirow{2}{*}{$\begin{array}{l}\text { MMS } \\
(\mathrm{mm})\end{array}$} & \multicolumn{2}{|c|}{ Range of Application } & \multirow{2}{*}{$\begin{array}{l}\text { Standard } \\
\text { (year) }\end{array}$} \\
\hline & & Areas & Main Species & \\
\hline \multirow{2}{*}{ Trawl codend } & 54 & $\begin{array}{l}\text { Yellow Sea, East China } \\
\text { Sea }\end{array}$ & all & $\begin{array}{l}\text { GB11779-1989, } \\
\text { (1989) }\end{array}$ \\
\hline & 39 & South China Sea & all & $\begin{array}{l}\text { GB11780-1989, } \\
(1989)\end{array}$ \\
\hline \multirow{3}{*}{ Drift Gillnet } & 137 & $\begin{array}{l}\text { Bohai Sea, Yellow Sea, } \\
\text { East China Sea }\end{array}$ & $\begin{array}{c}\text { Silver pomfret } \\
\text { (Pampus argenteus) }\end{array}$ & $\begin{array}{l}\text { SC119-1983 } \\
(1983)\end{array}$ \\
\hline & 90 & $\begin{array}{l}\text { Yellow Sea, East China } \\
\text { Sea }\end{array}$ & $\begin{array}{l}\text { Chinese herring } \\
\text { (Ilisha elongata) }\end{array}$ & $\begin{array}{l}\text { SC120-1983 } \\
(1983)\end{array}$ \\
\hline & 90 & $\begin{array}{l}\text { Bohai Sea, Yellow Sea, } \\
\text { East China Sea }\end{array}$ & $\begin{array}{c}\text { Spanish mackerel } \\
\text { (Scomberomorus } \\
\text { niphonius) }\end{array}$ & $\begin{array}{l}\text { SC121-1983 } \\
(1983)\end{array}$ \\
\hline $\begin{array}{l}\text { Codend of winged } \\
\text { stow nets }\end{array}$ & 50 & East China Sea & $\begin{array}{c}\text { Hairtail } \\
\text { (Trichiurus lepturus) }\end{array}$ & $\begin{array}{l}\text { SC4013-1995 } \\
(1995)\end{array}$ \\
\hline
\end{tabular}

${ }^{\mathrm{a}}$ GB-National Standard

${ }^{\mathrm{b}}$ The standard has been amended in 2005. The size remains unchanged.

${ }^{c}$ The standard has been amended in 2005 . The size is adjusted to $40 \mathrm{~mm}$.

${ }^{\mathrm{d}} \mathrm{SC}-$-Industry Standard

Source: Gazette of the Ministry of Agriculture of the People's Republic of China, 2003.

Table 2.

The number of marine engine-powered fishing vessels and total engine power.

\begin{tabular}{ccc}
\hline Year & $\begin{array}{c}\text { The number of marine } \\
\text { engine-powered fishing vessels }\end{array}$ & $\begin{array}{c}\text { The total engine power } \\
\text { ( in millions of kilowatts) }\end{array}$ \\
\hline $\mathbf{1 9 8 6}$ & $161,195^{\mathrm{a}}$ & 5.43 \\
$\mathbf{2 0 0 2}$ & 222,390 & 12.70 \\
$\mathbf{2 0 1 0}$ & $204,456(192,390)^{\mathrm{b}}$ & $13.04(11.43)^{\mathrm{b}}$ \\
$\mathbf{2 0 1 1}$ & 201,694 & 13.26 \\
\hline
\end{tabular}

${ }^{\mathrm{a}}$ The number included fishing and farming.

${ }^{\mathrm{b}}$ The number in the brackets was the goal of 2010.

Source: China Fisheries Yearbook 1986, 2002, 2010, 2011. 
Table 3.

Summer Moratorium of Fishing by area.

\begin{tabular}{|c|c|c|c|c|}
\hline & Areas & Time $^{a}$ & Duration & Others $^{\text {b }}$ \\
\hline Bohai Sea & The entire sea & Jun $1-$ Sept 1 & 3 months & I \\
\hline \multirow[b]{2}{*}{ Yellow Sea } & North of $35^{\circ} \mathrm{N}$ & Jun $1-$ Sept 1 & 3 months & I \\
\hline & South of $35^{\circ} \mathrm{N}$ & Jun 1-Sept 16 & 3.5 months & $\begin{array}{l}\text { The closing time for shrimp beam trawling and pots is from } \\
\text { June } 1 \text { st to August } 1 \text { st. The closing time for light seine is } \\
\text { from May } 1 \text { st to July 1st. }\end{array}$ \\
\hline \multirow{2}{*}{ East China Sea } & North of $26^{\circ} 30^{\prime} \mathrm{N}$ & Jun 1-Sept 16 & 3.5 months & $\begin{array}{l}\text { The closing time for shrimp beam trawling and pots is from } \\
\text { June } 1 \text { st to August } 1 \text { st. The closing time for light seine is } \\
\text { from May 1st to July 1st. }\end{array}$ \\
\hline & $\begin{array}{l}26^{\circ} 30^{\prime} \mathrm{N}-\text { the sea boundary line } \\
\text { between the Fujian and Guangdong } \\
\text { Provinces }\end{array}$ & May 16-Aug 1 & 2.5 months & / \\
\hline $\begin{array}{l}\text { South China Sea } \\
\text { (including Beibu } \\
\text { Gulf) }\end{array}$ & $\begin{array}{l}\text { The sea boundary line between the } \\
\text { Fujian and Guangdong Provinces - } \\
12^{\circ} \mathrm{N}\end{array}$ & May 16-Aug 1 & 2.5 months & l \\
\hline
\end{tabular}

Gulf)

${ }^{\mathrm{a}}$ Moratoria start and finish at noon (12:00).

${ }^{\mathrm{b}}$ All fishing gears and methods except angling and monolayer gillnets. The closing time for stow net is at least two and a half months.

Source: Gazette of the Ministry of Agriculture of the People's Republic of China, 2009. 